\title{
Penatalaksanaan Terkini Batu Saluran Kencing di RSUD Arifin Achmad Pekanbaru, Indonesia
}

\section{Current Management of Urinary Stones in Arifin Achmad Hospital Pekanbaru, Indonesia}

\author{
Zuhirman Zamzami ${ }^{1 *}$ \\ ${ }^{1} \mathrm{KJF}$ Bedah Fakultas Kedokteran Universitas Riau
}

\begin{abstract}
ABSTRAK
Batu saluran kencing merupakan masalah dalam bidang urologi yang memerlukan perhatian karena prevalensinya yang terus meningkat. Penelitian ini berujuan untuk mengevaluasi penatalaksanaan terkini penatalaksanaan batu saluran kencing di RSUD Arifin Achmad Pekanbaru. Penelitian ini merupakan penelitian retrospektif. Penelitiian dilaksanakan di rumahsakit Arifin Achmad Pekanbaru, Semua catatan medis pasien batu saluran kencing periode 2010-2016 direview untuk mendapatkan karakteristik, pola dan penatalaksanaan batu saluran kencing. Terdapat 1418 pasien batu saluran kencing yang ditatalaksana di RSUD Arifin Achmad Pekanbaru dimana yang terbanyak batu ureter (49,1\%) dan dikuti oleh batu ginjal (37,5\%) serta batu buli $(13,4 \%)$. Penatalaksanaan batu saluran kencing sebagian besar $(72 \%)$ dengan tindakan non invasif dan invasif minimal sedangkan $28 \%$ dengan tindakan operasi terbuka (invasif). Dapat disimpulkan penatalaksanaan terkini batu saluran kencing di RSUD Arifin Achmad Pekanbaru sebagian besar adalah tindakan non invasif dan minimal invasif sedangkan tindakan operasi terbuka (invasif) lebih sedikit. Terdapat perbaikan fungsi ginjal secara berbeda bermakna $(p<0,0001, p<0,002)$ kadar ureum dan kreatinin sebelum dan sesudah penatalaksanaan batu saluran kencing pada pasien batu saluran kencing dengan gangguan fungsi ginjal (uropati obstruktif).
\end{abstract}

Kata kunci: batu saluran kencing, invasif, gangguan ginjal, tata laksana

\begin{abstract}
Urinary stones are a problem in the field of urology that needs attention because of its increasing prevalence. This study aims to evaluate the current management of urinary tract stone in Arifin Achmad Hospital Pekanbaru. This study is a retrospective study. The study was conducted in Arifin Achmad Hospital Pekanbaru, all medical records of urinary tract stone patients period 2010-2016 reviewed to obtain characteristic, pattern and management of urinary tract stones. There were 1418 urinary tract stone patients treated at RSUD Arifin Achmad Pekanbaru where the most ureteral stones (49.1\%) and followed by kidney stones (37.5\%) and bladder stone (13.4\%). Most of treatment of urinary stones were non-invasive and minimally invasive (72\%), $28 \%$ with open (invasive) surgery. In conclusion, the current management of urinary tract stones in Arifin Achmad Hospital Pekanbaru is mostly non-invasive and minimally invasive action while less open (invasive) surgery. There were significant improvements in renal function $(p<0.0001, p<0.002)$ of ureum and creatinine levels before and after management urinary tract stone in urinary tract stone patients with impaired renal function (obstructive uropathy).
\end{abstract}

Keywords: impaired renal function, invasive, management, urinary stone

*Korespondensi: Zuhirman Zamzami, email: zuhirman.zamzami@yahoo.com

Artikel info: Online published first 25 April 2018; Received 25 September 2017; Accepted 1 Februari 2018.

DOI: https://doi.org/10.26891/jkm.v1i2.2018.60-66

Copyright @ 2018 Zuhirman Zamzami. This is an open access article distributed under the terms of the Creative Commons AttributionNonCommercial 4.0 International License (http://creativecommons.org/licenses/by-nc/4.0/), which permits unrestricted non-commercial use, distribution, and reproduction in any medium, provided the original author and source are properly cited. 
Batu saluran kencing (BSK) merupakan penyakit ketiga terbanyak di bidang urologi setelah infeksi saluran kencing dan pembesaran prostat jinak. ${ }^{1}$ Data di Indonesia menunjukkan BSK merupakan penyakit kedua terbanyak setelah infeksi saluran kencing dan penyakit terbanyak di antara penyakit-penyakit yang memerlukan tindakan di bidang urologi. ${ }^{2}$ Prevalensi BSK makin meningkat di seluruh dunia maupun di Indonesia. ${ }^{3}$ Di Indonesia BSK masih menempati porsi terbesar dari seluruh pasien di klinik urologi. Insidensi dan prevalensi BSK di Indonesia belum pasti. Data dalam negeri dari Rumah Sakit Umum Pusat Nasional Cipto Mangunkusumo menunjukkan terjadi peningkatan jumlah BSK yang mendapat tindakan yaitu $86 \%$ dari seluruh tindakan penatalaksanaan batu saluran kencing sejak dipergunakan alat noninvasive Extracorporeal Shockwave Lithotripsy (ESWL). ${ }^{2}$

Batu saluran kencing terdapat pada 7-10 dari 1000 pasien yang masuk ke rumah sakit. Laki-laki memiliki resiko mendapat BSK tiga kali lipat dibandingkan dengan wanita dengan umur puncak awal kejadian 20-40 tahun. ${ }^{4}$ Prevalensi sepanjang hidup BSK diperkirakan 1 - 15\%, dengan kemungkinan mendapat suatu batu berbeda-beda berdasarkan usia, jenis kelamin, ras dan lokasi geografi. ${ }^{5}$ Sebagian BSK memiliki dasar genetik, tetapi sebagian lagi sangat tergantung pada faktor lingkungan atau faktor gizi seperti diet tinggi protein. ${ }^{3,6}$

Berdasarkan lokasi, BSK dibagi menjadi (1) batu ginjal $27,1 \%$ (2) batu ureter $51,8 \%$ (3) batu buli $18,1 \%$ (4) dan batu urethra 3\% . ${ }^{7,8}$ Pada keseluruhan BSK di RSUD Arifin Achmad Pekanbaru, batu ureter adalah yang terbanyak (51,8\%), dimana batu ureter proksimal $22,6 \%$ yang termasuk batu ureter di persilangan vasa iliaka sekitar 7,5\% dan batu ureter distal 29,2\%. ${ }^{8}$ Sebagian besar batu ureter akan berada pada ureter sepertiga bawah (56,8-75\%), diikuti secara berturut-turut oleh batu ureter proksimal atau ureteropelvic junction (24,6-43,8\%) termasuk batu ureter di persilangan vasa iliaka (9,3-28,3\%). 9,10

Batu buli pada umumnya berasal dari batu ginjal yang turun (jatuh) ke ureter dan apabila batu ureter lolos spontan sampai berhenti dibuli maka batu tersebut merupakan batu buli. ${ }^{6,8,9}$ Pada pasien yang satu kali batu ureternya lolos spontan ke buli, kemungkinan satu lagi BSKnya lolos spontan adalah sekitar $15 \%$ menjelang 3 tahun dan sekitar 30\% menjelang 15 tahun. BSK merupakan penyakit seumur hidup, dengan rata-rata masa jeda antara setiap episode penyakit rata-rata 9 tahun. ${ }^{11}$
Terdapat beberapa faktor yang mendorong pembentukan BSK yaitu (1) peningkatan kadar kristaloid pembentuk batu dalam urin (2) $\mathrm{pH}$ urin abnormal rendah atau tinggi (3) berkurangnya zat-zat pelidung dalam urin dan (4) sumbatan saluran kencing dengan stasis urin. ${ }^{12}$ Disamping itu, terdapat pula tiga faktor utama yang harus dipertimbangkan untuk terjadinya BSK yaitu: retensi partikel urin, supersaturasi urin, dan kekurangan inhibitor kristalisasi urin. Kelebihan salah satu faktor ini menyebabkan batu saluran kencing. ${ }^{7}$

Batu saluran kencing diklasifikasikan sebagai batu ginjal (nefrolithiasis), batu ureter (ureterolithiais), batu buli (vesikolithiasis) dan batu urethra (urethrolithiasis). Batu ginjal yang terdiri atas batu pyelum (pyelolithiasis), batu kalik (kalikolithiasis), batu infundibulum (infundibulolithiasis), batu multipel ginjal, batu cetak ginjal (Staghorn stone) yang komplit, inkomplit. Batu ureter (ureterolithiasis) terdiri atas batu ureter proksimal (ureterolithiasis proksimal), batu ureteropelvic junction, batu ureter tengah (ureterolithiasis tengah) dan batu ureter distal (ureterolithiasis distal). Batu buli (vesikolithiasis) terdiri atas batu buli kecil (diameter terbesar $30 \mathrm{~mm}$ ), batu buli besar (diameter terbesar $>30 \mathrm{~mm}$ ), batu buli sangat besar (Huge Bladder Stone) dan batu Bladder Neck. Batu urethra (urethrolithiasis) terdiri atas batu urethra posterior dan batu urethra anterior. ${ }^{8,13}$

Gejala klinis batu saluran kencing bisa mulai dari tanpa gejala (asimptomatis), bergejala sampai gagal ginjal. Gejala klinis simptomatis bisa berupa gejala klasik dan atau gejala komplikasi. Gejala klasik dapat berupa sakit pnggang (kolik atau non kolik), dan gejala komplikasi seperti buang air kecil berdarah (hematuria), keluar batu saluran kencing spontan, deman bahkan sampai gagal ginjal. Pemeriksaan fisik batu saluran kencing dimulai dari pemeriksaan status generalisata (umum) dan pemeriksaan status lokalis urologi. Temuan pada pemeriksaan fisik status generalisata dapat merupakan gambaran dari hasil dari pemeriksaan fisik status lokalis urologi dan sebaliknya. $^{8}$

Pemeriksaan penunjang untuk mendukung penegakkan diagnosis batu saluran kencing adalah pemeriksaan laboratorium, pemeriksaan radiologi, pemeriksaan kedokteran nuklir. Pemeriksaan laboratorium adalah pemeriksaan urinalisis, pemeriksaan darah rutin, pemeriksaan kimia darah. Pemeriksaan kedokteran nuklir adalah pemeriksaan renografi dan laju filtrasi glomerulus (Glomerular Fitration Rate $=$ GFR). Pemeriksaan urinalisis 
merupakan pemeriksaan awal yang penting untuk membantu penegakkan diagnosis dan menilai komplikasi batu saluran kencing. Pemeriksaan kimia darah yang penting untuk batu saluran kencing adalah pemeriksaan kadar ureum dan kreatinin darah untuk menilai kedua fungsi ginjal secara keseluruhan. Pemeriksaan radiologi untuk penegakkan diagnosis batu saluran kencing adalah BNO-IVP, ultrasonografi ginjal ureter, buli dan prostat, serta pemeriksaan Computerized Tomography (CT) scan. Pemeriksaan renografi dan laju filtrasi glomerulus adalah untuk menilai fungsi ginjal secara terpisah (split kidney function) secara kuantitatif dan kualitatif. ${ }^{8}$

Penatalaksanaan batu saluran kencing tergantung pada klasifikasi batu saluran kecingnya. Jenis penatalaksanaan batu ginjal dapat berupa konservatif (observasi), non invasif dengan Extracorporeal Shockwave Lithotripsy (ESWL), invasif minimal dengan Ureterorenoscopy (URS) + Disintegrasi batu dan Percutaneous Nephrolithotripsy (PCNL), dan operasi terbuka (nefrolithotomi, pielolithotomi atau nefrektomi. Penatalaksanaan batu ureter dapat berupa tindakan konservatif (observasi/menunggu) karena batu ureter ukuran diameter sampai $5 \mathrm{~mm}$ dapat melewati ketiga tempat penyempitan tersebut. Bila tindakan konservatif tersebut gagal, perlu intervensi seperti ESWL, URS + disintegrasi batu atau ureterolithotomy. ${ }^{14}$ Pada penatalaksanaan batu ginjal dan batu ureter selain tidakan diatas kadang-kadang diperlukan pemasangan suatu alat Double J Stent atas indikasi tertenntu seperti batu ginjal multipel, batu cetak ginjal, batu ginjal dengan gangguan fungsi ginjal atau single kidney. Pada penatalaksanaan batu ureter pemakaian Double J Stent dilakukan pada gangguan fungsi ginjal, single kidney atau disertai fibrosis ureter. $^{15}$

Penatalaksanaan batu buli terutama tergantung pada ukuran batu buli dan modalitas (alat) yang tersedia. Vesicolithotrpsy dilakukan pada batu buli yang berukuran kecil dan vesikolithotomy (Sectio Alta). Tindakan ESWL terhadap batu buli yang kecil belum banyak dipublikasikan. Penatalaksanaan terhadap batu urethra adalah urethrotomi eksterna atau pushback yang dilanjutkan dengan vesicolithotripsy. Bila tidak dilakukan tindakan (intervensi) terhadap batu saluran kencing dapat terjadi sumbatan/obstruksi di sebelah atas sumbatan dengan segala komplikasinya. ${ }^{15,16}$

Sejak tahun 2010 di RSUD Arifin Achmad Pekanbaru sudah tersedia alat-alat non invasif (ESWL) dan alat minimal invasif seperti URS dan disintegrasi. Belum adanya penelitian tentang penatalaksanan batu saluran kencing di RSUD Arifin Achmad, sehingga perlu dilakukan penelitian tentang hal tersebut.

\section{METODE}

Jenis penelitian adalah retrospektif dengan pendekatan cross-sectional (potong lintang). Populasi adalah pasien batu saluran kencing yang dilakukan penatalaksanaan di RSUD Arifin Achmad Pekanbaru. Sampel adalah bagian dari populasi yang memenuhi kriteria inklusi dan eksklusi di Bagian Urologi RSUD Arifin Achmad Propinsi Riau. Jumlah sample adalah total sampling. Kriteria inklusi: (1) Pasien yang didiagnosis batu saluran kencing dan dilakukan penatalasanaan non invasif, minimal invasif atau invasif di RSUD Arifin Achmad Pekanbaru tahun 2010 - 2016 dan (2) Data rekam medis lengkap.

Data dikumpulkan dari catatan medik pasien yang meliputi diagnosis, dan penatalaksanaan non invasif, invasif minimal atau invasif. Waktu pengumpulan dan pengolahan data: April - Juni 2017. Waktu penyelesaian penelitian: Juli 2017. Variabel penelitian ini: batu saluran kencing, jenis kelamin, umur, pemeriksaan penunjang, penatalaksanaan. Data-data yang telah didapatkan dikelompokkan sesuai dengan parameter yang ingin diketahui kemudian diolah secara manual serta disajikan secara deskriptif dalam bentuk tabel distribusi frekuensi untuk menarik kesimpulan.

\section{HASIL DAN PEMBAHASAN}

Pada penelitian ini didapatkan 1418 rekam medik pasien yang terdiri dari $951(67,1 \%)$ adalah laki-laki dan 467 (32,9\%) adalah perempuan, dengan perbandingan 2: 1 . Jumlah pasien terbanyak berdasarkan kelompok umur yaitu pada umur 40-49 tahun sebanyak 407 orang $(28,7 \%)$, dan yang paling sedikit pada kelompok umur $<20$ tahun sebanyak 27 orang $(1,9 \%)$.

Tabel 1 menunjukkan distribusi frekuensi diagnosis dengan Diagnosis batu ginjal 532 orang (37,5\%), batu ureter 696 orang $(49,1 \%)$ dan batu Buli 190 orang $(13,4 \%)$. pasien yang terdiagnosis batu ginjal paling banyak terdapat pada kelompok umur 40-49 tahun sebanyak 180 pasien (33,8\%) dan pasien yang terdiagnosis batu ureter paling banyak terdapat pada kelompok umur 40-49 tahun sebanyak 203 pasien $(29,2 \%)$ serta pada pasien batu buli paling banyak pada kelompok umur 50-59 tahun sebanyak 59 pasien (31,1\%). 
Tabel 1. Distribusi frekuensi diagnosa pasien batu ginjal dan batu ureter berdasarkan umur

\begin{tabular}{cccccccc}
\hline \multicolumn{9}{c}{ umur } & \multicolumn{9}{c}{ Batu Ginjal } & \multicolumn{2}{c}{ Batu Ureter } & \multicolumn{2}{c}{ Batu Buli } & Total \\
& $\mathbf{n}$ & $\mathbf{f ~ ( \% )}$ & $\mathbf{n}$ & $\mathbf{f ~ ( \% )}$ & $\mathbf{n}$ & $\mathbf{f ~ ( \% )}$ \\
& 0 & 0 & 15 & 2,2 & 12 & 6,3 & 27 \\
\hline$<20$ & 25 & 4,7 & 70 & 10,2 & 20 & 10,5 & 115 \\
$20-29$ & 112 & 21,1 & 193 & 27,7 & 25 & 13,2 & 330 \\
$30-39$ & 180 & 33,8 & 203 & 29,2 & 24 & 12,6 & 407 \\
$40-49$ & 135 & 25,4 & 145 & 20,8 & 59 & 31,1 & 339 \\
$50-59$ & 63 & 11,8 & 57 & 8,2 & 39 & 20,5 & 159 \\
$60-69$ & 17 & 3,2 & 13 & 1,7 & 11 & 5,8 & 41 \\
$\geq 70$ & & & & & & &
\end{tabular}

Tabel 2 menujukkan distribusi frekuensi pemeriksaan urinalisis ditemukan lengkap pada 452 (31,9\%) pasien. Hasil pemeriksaan makroskopik ditemukan berat jenis urin terbanyak adalah 1,003-1,030 $(93,8 \%)$, warna urin terbanyak adalah warna kuning keruh (46\%), pH urin menunjukan hasil normal (100\%) dengan rata-rata $\mathrm{pH}$ adalah 6. Pemeriksaan mikroskopik ditemukan sedimen urin meliputi eritrosit, leukosit, kristal dan epitel dengan eritrosit terbanyak adalah $>1(98,7 \%)$, leukosit terbanyak $>5$ $(52,7 \%)$, tidak ditemukannya kristal urin $(99,1 \%)$ dan epitel urin terbanyak adalah $<15(85,4 \%)$.

Tabel 2. Distribusi frekuensi pemeriksaan urinalisis

\begin{tabular}{|c|c|c|}
\hline Pemeriksaan urinalisis & $\mathbf{n}$ & $f(\%)$ \\
\hline \multicolumn{3}{|l|}{ Berat jenis } \\
\hline$<1,003$ & 4 & 0,9 \\
\hline $1,003-1,030$ & 424 & 93,8 \\
\hline$>1,030$ & 24 & 5,3 \\
\hline \multicolumn{3}{|l|}{ Warna urin } \\
\hline Kuning muda jernih & 116 & 25,7 \\
\hline Kuning jernih & 128 & 28,3 \\
\hline Kuning keruh & 208 & 46 \\
\hline \multicolumn{3}{|l|}{$\mathrm{pH}$} \\
\hline$<4,5$ & 0 & 0 \\
\hline $4,5-8,0$ & 452 & 100 \\
\hline$>8,0$ & 0 & 0 \\
\hline \multicolumn{3}{|l|}{ Eritrosit } \\
\hline $0-1$ & 6 & 1,3 \\
\hline$>1$ & 446 & 98,7 \\
\hline \multicolumn{3}{|l|}{ Leukosit } \\
\hline $0-5$ & 214 & 47,3 \\
\hline$>5$ & 238 & 52,7 \\
\hline \multicolumn{3}{|l|}{ Kristal } \\
\hline Positif & 4 & 0,9 \\
\hline Negatif & 448 & 99,1 \\
\hline \multicolumn{3}{|l|}{ Epitel } \\
\hline$<15$ & 386 & 85,4 \\
\hline$\geq 15$ & 66 & 14,6 \\
\hline \multicolumn{3}{|l|}{ Protein } \\
\hline Positif & 196 & 43,4 \\
\hline Negatif & 256 & 56,6 \\
\hline \multicolumn{3}{|l|}{ Keton } \\
\hline Negatif & 442 & 97,8 \\
\hline Positif & 10 & 2,2 \\
\hline \multicolumn{3}{|l|}{ Glukosa } \\
\hline Positif & 198 & 43,8 \\
\hline Negatif & 254 & 56,2 \\
\hline
\end{tabular}

Dari pemeriksaan urinalisis yang dilakukan lebih banyak tidak ditemukannya protein didalam urin $(56,6 \%)$, pada keton juga kebanyakan tidak ditemukannya keton di dalam urin $(97,8 \%)$.

Rerata ureum sebelum dilakukan penatalaksanaan adalah sebagai berikut 45,6 mg/dL, kadar tertinggi $141,2 \mathrm{mg} / \mathrm{dL}$ dan kadar terendah yaitu $10 \mathrm{mg} / \mathrm{dL}$ dan rerata kreatinin $2,5 \mathrm{mg} / \mathrm{dL}$, kadar tertinggi $8,7 \mathrm{mg} / \mathrm{dL}$, dan kadar terendah yaitu $0,2 \mathrm{mg} / \mathrm{dL}$.

Pemeriksaan penunjang radiologi yang paling banyak dipakai adalah BNO-IVP $(53,9 \%)$ diikuti oleh USG traktus urinarius $(26,15)$. Pemeriksaan CT scan traktus urinarius tanpa media kontras lebih banyak dipakai (15\%) dibandingkan dengan CT scan traktus urinarius dengan media kontras (5\%).

Tabel 3. Distribusi frekuensi pasien berdasarkan lokasi batu

\begin{tabular}{lcc}
\hline \multicolumn{1}{r}{ Lokasi } & n & $\mathbf{f ( \% )}$ \\
\hline Ginjal & 532 & 37,5 \\
Ureter & 696 & 49,1 \\
Buli & 190 & 13,4 \\
\hline Total & $\mathbf{1 4 1 8}$ & $\mathbf{1 0 0}$ \\
\hline
\end{tabular}

Pada penelitian ini didapatkan lokasi batu terbanyak yang ditatalaksana yaitu pada batu ureter 696 orang $(49,1 \%)$, diikuti dengan di ginjal 532 orang $(37,5 \%)$. (Tabel 3) Berdasarkan jenis kelamin, penderita batu ginjal dan batu ureter lebih banyak terjadi pada lakilaki dibanding dengan perempuan. (Tabel 4)

Tabel 4. Distribusi frekuensi diagnosa pasien batu ginjal dan batu ureter berdasarkan jenis kelamin

\begin{tabular}{lcccccc}
\hline & \multicolumn{3}{c}{ Jenis Kelamin } & \multicolumn{2}{l}{ Total } \\
Lokasi batu & Laki Laki & \multicolumn{2}{c}{ Perempuan } & & \\
& $\mathbf{n}$ & $\mathbf{f ( \% )}$ & $\mathbf{n}$ & $\mathbf{f ~ ( \% )}$ & $\mathbf{N}$ & $\mathbf{F ~ ( \% )}$ \\
\hline Batu Ginjal & 331 & 62,2 & 201 & 37,8 & 532 & 100 \\
Batu Ureter & 451 & 64,8 & 245 & 35,2 & 696 & 100 \\
Batu Buli & 169 & 88,9 & 21 & 11,1 & 190 & 100 \\
\hline
\end{tabular}

Tabel 5 memperlihat distribusi frekuensi pasien berdasarkan tahun terhadap tatalaksana batu saluran kencing. Dari table terlihat bahwa terjadi peningkatan penatalaksanaan setiap tahunnya. Jumlah pasien terbanyak yang ditatalaksana yaitu pada tahun 2016 sebanyak 489 orang dan paling sedikit pada tahun 2010 sebanyak 75 orang, dengan catatan ESWL di RSUD Arifin Achmad mulai dibuka tahun 2011 kemudian pada tahun 2015 terjadi kerusakan alat ESWL hampir 1 tahun penuh. Selama tujuh tahun terdapat 1418 pasien batu saluran kencing yang ditatalaksana di RSUD Arifin Achmad Pekanbaru 
dimana dimana $72 \%$ (1016) adalah tindakan non invasif (ESWL = 839) dan invasif minimal (Vesikolithotripsi $=94$, dan URS + lithotripsy $=83$ ), sedangkan tindakan invasif (operasi terbuka\} lebih sedikit (28\%).

Tabel 5. Distribusi frekuensi pasien batu saluran kencing berdasarkan tahun terhadap tatalaksana

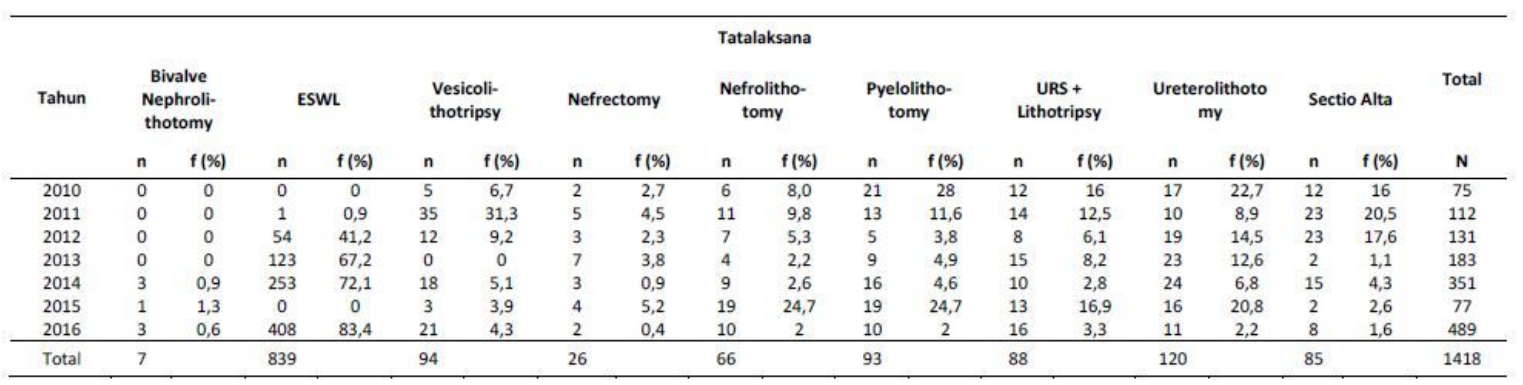

Setelah dilakukan tata laksana terdapat hubungan yang signifkan kadar ureum dan kreatinin sebelum dan sesudah dilakukan operasi $(p<0,05)$. (Tabel 6$)$

Tabel 6. Distribusi perbedaan kadar ureum dan kreatinin sebelum dan sesudah penatalaksanaan pada pasien dengan gangguan fungsi ginjal

\begin{tabular}{lcccc}
\hline $\begin{array}{c}\text { Pemeriksaan } \\
\text { fungsi ginjal }\end{array}$ & $\begin{array}{c}\text { Mean } \\
\text { (mg/dL) }\end{array}$ & $\mathbf{n}$ & $\mathbf{r}$ & $\mathbf{p}$ \\
\hline Ureum & & & & \\
$\quad$ Preoperatif & 45,6 & 62 & 0,186 & 0,0001 \\
$\quad \begin{array}{c}\text { Postoperatif } \\
\text { Kreatinin }\end{array}$ & 28,9 & & & \\
$\quad$ preoperatif & 2,5 & 62 & 0,746 & 0,002 \\
$\quad$ Postoperative & 1,9 & 62 & \\
\hline
\end{tabular}

Distribusi frekuensi penderita batu ginjal dan ureter berdasarkan jenis kelamin pada Tabel 1 menunjukkan bahwa jumlah pasien laki-laki lebih banyak daripada perempuan yaitu dengan perbandingan 1,8: 1 . Penelitian sebelumnya oleh Suka EFM (2007) di RSUD Arifin Achmad tahun 2002-2006 menemukan perbandingan lebih tinggi pada penderita laki-laki dengan 214 kasus $(81,7 \%)$ dan 64 kasus $(24,4 \%)$ untuk wanita dengan perbandingan rasio 4,5:1. ${ }^{17}$ Pada penelitian oleh Felicia Suryanto (20015) tahun 20132014 di RSUP Sanglah Denpasar didapatkan perbandingan penderita batu saluran kemih yang berjenis kelamin laki-laki dengan penderita yang berjenis kelamin perempuan adalah sebesar $2,9: 1 .{ }^{18}$ Perbedaan di atas bisa terjadi karena secara anatomis saluran kemih laki-laki lebih panjang dibandingkan wanita. Hal ini memungkinan adanya pengendapan substansi batu lebih besar pada saluran kemih lakilaki. Penyebab signifikan lain adalah kadar kalsium air kemih sebagai bahan utama pembentuk batu lebih rendah pada perempuan daripada laki-laki, dan kadar sitrat air kemih sebagai bahan penghambat terjadinya batu pada perempuan lebih tinggi daripada laki-laki.
Selain itu, hormon estrogen pada perempuan mampu mencegah agregasi garam kalsium, sedangkan hormon testosteron yang tinggi pada laki-laki menyebabkan peningkatan oksalat endogen oleh hati yang selanjutnya memudahkan terjadinya kristalisasi. Pada penelitian yang dilakukan sekarang dan terdahulu menunjukan bahwa laki-laki lebih sering menderita batu saluran kemih dibandingkan dengan perempuan. Terdapat sedikit perbedaan hasil antara penelitian yang dilakukan sekarang dengan penelitian terdahulu, hal ini mungkin disebabkan oleh perbedaan lamanya waktu dan jumlah sampel dalam melakukan penelitian.

Hasil penelitian ini menunjukkan bahwa umur yang paling banyak menderita batu ginjal dan ureter adalah kelompok umur 40-49 tahun, batu ginjal sebanyak 180 orang $(33,8 \%)$ dan batu ureter sebanyak 203 orang (29,2\%). dan paling sedikit pada kelompok umur $<20$ tahun adalah 10 orang $(1,8 \%)$. Hasil yang didapat sesuai dengan penelitian sebelumnya yang dilakukan oleh Suka EFM di RSUD Arifin Achmad Pekanbaru tahun 2002 sampai 2006 menemukan bahwa kelompok umur terbanyak ditemukan pada kelompok umur 40-49 tahun $(24,4 \%) .{ }^{17}$ Penelitian ini sejalan dengan kepustakaan yang menyatakan bahwa penyakit ini umumnya didapatkan pada dekade ketiga sampai dekade kelima. Batu saluran kemih merupakan penyakit kronis yang memerlukan jangka waktu yang cukup lama dan perlahan-lahan akan merusak saluran kemih. Dengan bertambahnya umur menyebabkan gangguan peredaran darah seperti hipertensi dan kolesterol tinggi. Hipertensi dapat menyebabkan pengapuran ginjal yang dapat berubah menjadi batu, sedangkan kolesterol tinggi merangsang agregasi dengan kristal kalsium oksalat dan kalsium fosfat sehingga mempermudah terbentuknya batu. ${ }^{19}$ 
Distribusi frekuensi penderita batu ginjal dan ureter berdasarkan lokasi batu pada tabel 4.3 menunjukkan bahwa jumlah lokasi batu terbanyak terdapat pada batu ureter 566 orang $(49,1 \%)$ dengan lokasi pada batu ureter distal 342 (38,4\%). Penelitian lain yang dilakukan di RSUD Arifin Ahmad Pekanbaru (2010) didapatkan distribusi frekuensi batu saluran kemih menurut lokasi batu adalah batu ginjal $28,3 \%$, batu ureter $51,8 \%$, batu buli $18,8 \%$, batu urethra $3 \%$ (Zuhirman, 2011). ${ }^{8}$

Lokasi batu terbanyak terjadi pada batu ureter. Hal ini sesuai dengan kepustakaan yang menyatakan ureter merupakan saluran kecil yang menghubungkan ginjal dan buli. Ureter ini menyempit di 3 tempat yaitu di (1) perbatasan antara ureter dengan pelvis renalis atau dikenal dengan ureteropelvic junction, (2) persilangan antara ureter dengan arteri iliaka di rongga pelvis, dan (3) saat ureter masuk ke dalam kandung kemih. Secara umum, batu yang berukuran kecil dengan diameter maksimum $5 \mathrm{~mm}$ akan mampu melewati ureter dan biasanya keluar bersama urine tetapi batu ureter tersebut dapat juga tersangkut di ketiga tempat tersebut yang menyebabkan nyeri (kolik ureter). ${ }^{19}$

Pasien yang didiagnosis batu ginjal pada penelitian ini lebih banyak pada kelompok umur 40-49 tahun sebanyak 180 orang dari 532 pasien batu ginjal $(33,8 \%)$. Pasien yang didiagnosis batu ureter pada penelitian ini lebih banyak pada kelompok umur 4049 tahun sebanyak 203 orang dari 696 pasien batu ureter (29,2\%). Pasien yang didiagnosis batu buli pada penelitian ini lebih banyak pada kelompok umur 5059 tahun sebanyak 59 orang dari 190 pasien batu buli (31,1\%).

Pemeriksaan penunjang radiologi yang paling banyak dipakai adalah BNO-IVP $(53,9 \%)$ diikuti oleh USG traktus urinarius $(26,15)$. Pemeriksaan CT scan traktus urinarius tanpa media kontras lebih banyak dipakai ((15\%) dibandingkan dengan CT scan traktus urinarius dengan media kontras (5\%). Pemeriksaan Pemeriksaan CT scan traktus urinarius tanpa media kontras pada umumnya dipakai pada keadaan pasien batu saluran kencing dengan gangguan fungsi ginjal, pada hasil BNO-IVP non-visualized atau pada batu saluran kencing radiolusen.

Penelitian ini menunjukkan bahwa laki-laki sering mengalami kejadian batu saluran kemih dibandingkan perempuan, baik batu ginjal $(62,2 \%)$, batu ureter $(64,8 \%)$, maupun batu buli $(88,9 \%)$. Penelitian lain menyatakan bahwa batu ginjal lebih banyak diderita oleh laki-laki, dengan angka kejadian 3 kali lebih banyak daripada perempuan.
Terjadi peningkatan penatalaksanaan batu ginjal dan batu ureter dengan ESWL (minimal invasive) dan Ureteroskopi + Ureterolithotripsi serta vesikolothotripsy di RSUD Arifin Achmad Pekanbaru setiap tahunnya dari 2010 sampai 2016. Jumlah pasien terbanyak yang ditatalaksana yaitu pada tahun 2016 sebanyak 411 orang dan paling sedikit pada tahun 2010 yaitu 11 orang. Menurut Sahar-Fathallah tahun 2014 dalam jurnal penelitiannya bahwa telah terjadi peningkatan yang signifikan dalam jumlah pasien yang didiagnosa dengan batu saluran kemih sejak dekade terakhir ini. ${ }^{18}$

Peningkatan dalam kejadian batu saluran kemih dari tahun ke tahun dapat disebabkan semakin berkembangnya teknologi kedokteran untuk pilihan terapi batu ginjal dan ureter. Penjelasan lainnya adalah bahwa globalisasi membawa perkembangan sosial yang besar seperti mengadopsi gaya hidup yang lebih kebarat-baratan yang dapat berkontribusi meningkatnya penyakit batu saluran kemih. Perubahan dalam gaya hidup seperti asupan cairan yang sedikit menurunkan jumlah urin sehingga mengakibatkan peningkatan reaktan (kalsium dan oksalat) dan pengurangan aliran urin. Diet yang kaya protein hewani dan karbohidrat serta meningkatnya konsumsi makanan yang mengandung kalsium, produk susu, oksalat (misalnya teh, kopi, coklat, kacang-kacang, bayam) yang dapat mengakibatkan peningkatan dalam kasus batu saluran kemih. ${ }^{20}$

Peneliti mengalami beberapa kesulitan dalam mengumpulkan data. Keterbatasan yang ditemui peneliti yaitu data rekam medis yang kurang lengkap dan tulisan yang sulit dibaca atau kurang teratur. Halhal tersebut menyebabkan peneliti tidak memperoleh data rekam medis secara keseluruhan.

\section{SIMPULAN}

Kasus batu saluran kemih lebih sering terjadi pada laki-laki dibandingkan dengan perempuan dengan ureter merupakan lokasi batu saluran kemih tersering. Batu buli lebih sering ditemukan pada kelompok usia dewasa akhir. Terdapat perbaikan fungsi ginjal yang berbeda secara bermakna kadar ureum dan kreatinin sebelum dan sesudah penatalaksanaan batu saluran kencing pada pasien batu saluran kencing dengan gangguan fungsi ginjal (uropati obstruktif).

Peneliti menyarankan Pemeriksaan urinalisis yang lengkap perlu juga disediakan di Instalasi Gawat Darurat, pengisian kelengkapan data dan penyimpanan rekam medis dengan baik, perlu penyediaan alat PCNL sehingga penatalaksanaan batu 
saluran kecing menjadi lengkap (sempurna), dan perawatan dan penilaian fungsi alat harus selalu dilakukan.

\section{DAFTAR PUSTAKA}

1. Stoller ML. Urinary Stone Disease. In (Tanagho EA, McAninch JW, eds). Smith's General Urology, $17^{\text {th }}$ ed 2008. New York: McGraw Hill Companies; 2008: 246275.

2. Hamid AR, Raharjo Dj. Evaluasi Penatalaksanaan Batu Ginjal Di RSCM tahun 1997 -2004 ,. Makalah. Subbagian Urologi Departemen IImu Bedah Fakultas Kedokteran Universitas Indonesia, RSUPN Cipto Mangunkusumo; 2004. Jakarta

3. Pearle, M.S, Lotan, Y. Urinary Lithiasis: Etiology, Epidemiology, and Pathogenesis. In: (Wein., Kavoussi., Novick., Partin., Peters, eds). CampbellWalsh Urology $10^{\text {th }}$ ed.Elseiver Saunders; Philadelphia; 2011:1363-1430.

4. Pahira JJ, Pevzner M,. Nephrolithiasis. In (Hanno PM, Malkowicz SB, Wein AJ, eds). Penn Clinical Manual of Urology. Philadephia: Saunders; 2007. $235-257$

5. Pearle, M.S., Lotan, Y. Urinary Lithiasis: Etiology, Epidemiology, and Pathogenesis. In: (Wein., Kavoussi., Novick., Partin., Peters, eds). CampbellWalsh Urology $10^{\text {th }}$ ed,.Elseiver Saunders., Philadelphia; 2011. 1363-1430.

6. Pak CYC, Resnick MI. Introduction. In (Resnick MI, Pak CYC, eds). Urolithiasis. A Medical and Surgical Reference.Philadelpia. W.B. Saunders Company; 1990. 1-9

7. Blandy J, Kaisary A . Urinary Calculi. In (Blandy J, Kaisary A, eds) Lecture Notes. Urology. 6 ${ }^{\text {th }}$ Ed, 2009. Singapore. Wiley Blackwell; 2009. 67-81

8. Zuhirman, 2010. Batu Saluran Kemih di RSUD Arifin Achmad Pekanbaru. Makalah SubBagian Urologi. Bagian Bedah, Fakultas Kedokteran Universitas Riau; 2010.Pekanbaru.

9. Resnick MI, Spirnak JP. Surgery of Kidney and Ureteral Stones. In (Resnick MI, Pk CYC, eds). Urolithiasis. A Medical and Surgical Reference. Philadelpia. W.B. Saunders Company ; 1990. 201-252

10. Shrestha B, Karki DV, Baidya JL. The outcome of pneumatic lithotripsy for the management of ureteric calculi. Kathmandu University Medical Journal: 2008.6;3;23;355-360

11. Anglade RE, Wang DS, Babayan RK. Urinary calculi and Endourology. In (Siroky MB, Oates RD, Babayan RK, eds). Principles of Urology: Diagnosis and Therapy 3rd ed. Philadelphia :Lippincott Williams \& Wilkins; 1999. 232-248.

12. Wyker, A.W, 1975. Calculi .In :(Wyker AW, Gillenwater JY, eds). Method of Urology.The Williams \& Wilkins Company., Baltimore; . 1975. 128-47

13. Anderson JK, Cadedu JA,. Surgical Anatomy of the Retroperitoneum, Adrenals, Kidneys, and Ureters. In (Kavoussi LR, Novick AC, Partin AW, Peters CA, eds). Campell-Walsh Urology. 10 ${ }^{\text {th }}$ ed; Philadelpia: Elsevier Saunders; 2011.3-70

14. Matlaga BR, Lingeman JE. Surgical Management of Upper Urinary Tract Calculi. In (Kavoussi LR, Novick AC, Partin AW, Peters CA, eds). Campbell-Walsh

\section{KONFLIK KEPENTINGAN}

Tidak ada
15. Urology. $10^{\text {th }}$ ed,. Philadelpia. Elsevier Saunders; 2011.1357-1410

16. Tiselius HG, Ackermann, Alken P, Buck C, Conort P, Galluci M, Guidelines on Urolithiasis. European Association of Urology. 2013

17. Tanagho EA. Urinary Obstruction \& Stasis. In (Tanagho EA, McAnnich JW, eds) Smith's General Urology, $17^{\text {th }}$ ed. New York:McGraw Hill Companies; , 2008:166-178

18. Suka EFM, Profile of urinary stone in Arifin Achmad Regional General Hospital, Pekanbaru, Riau, Indonesia in Januari 2002 - Desember 2006. [Scription], Medical Faculty, Riau University, 2007, 44

19. Felicia S, Evaluation of Extracorporeal Shockwave Lithotripsy in Arifin Achmad Regional General Hospital Pekanbaru, Indonesia.[Sciption].Medical Faculty, Riau University ; 2012. Pekanbaru

20. Pak CYC. Uric Acid Nephrolithiasis. In (Resnick MI, Pak CYC, eds) Urolithiasis. A Medical and Surgical Reference. Philadelpia. W.B. Saunders Company; 1990. 105-130

21. Cendron M, Sant GR, Klauber GT,. Ureteral Pathophysiology. In (Sant GR,ed). Pathophysiologic Principles of Urology. Boston : Blackwell Scientific Publications; 1994. 61-92 